\title{
Büyüme Hormonu Eksikliğinin Tanı Kriterleri Yeniden Değerlendirilmelidir
}

\section{Diagnostic Criteria of Growth Hormone Deficiency Needs to be Reevaluated}

\author{
Enes Salı, Halil Sağlam*, \\ Ömer Tarım* \\ Uludağ Üniversitesi Tıp Fakültesi Çocuk \\ Sağlı̆ı̆ ve Hastalıkları Anabilim Dalı, \\ Bursa, Türkiye \\ *Uludağ Üniversitesi Tıp Fakültesi \\ Çocuk Sağlığı ve Hastalıkları Anabilim \\ Dalı, Çocuk Endokrinoloji Bilim Dalı, \\ Bursa, Türkiye
}

Yazışma Adresi/Address for Correspondence Dr. Halil Sağlam,

Uludağ Üniversitesi Tıp Fakültesi Çocuk Sağıı̆ı ve Hastalıkları Anabilim Dalı, Cocuk Endokrinoloji Bilim Dalı, Bursa, Türkiye Tel. +902242950443 E-posta: drhali@uludag.edu.tr

Geliş Tarihi/Received: 20.06.2012 Kabul Tarihi/Accepted: 04.09.2012

(c) Güncel Pediatri Dergisi, Galenos Yayınevi tarafindan basılmıștır.

(c) The Journal of Current Pediatrics, published by Galenos Publishing.

\section{ÖZET}

Giriş: Bu çalışmada, hastanemizde büyüme hormonu (BH) eksikliği tanısıyla izlenen çocuklarda tedaviye yanıtı belirleyen etkenlerin belirlenmesi amaçlanmıştır.

Gereç ve Yöntem: Izole idyopatik BH eksikliği nedeniyle takip edilen ve BH tedavisi kullanan toplam 149 hastanın verileri retrospektif olarak incelendi.

Bulgular: Tanı aşamasında bakılan ortalama maksimum BH yanıtı klonidin stimülasyon testi için 4,58 $\mathrm{ng} / \mathrm{ml}$, glukagon stimülasyon testi için ise $6,01 \mathrm{ng} / \mathrm{ml}$ bulundu. Ortalama BH dozu $0,215(0,18-0,25) \mathrm{mg} / \mathrm{kg} / \mathrm{hafta}$ olarak belirlendi. BH tedavisi ile boy SDS anlamlı olarak arttı $(p<0,05)$. Klonidin ve glukagon uyarısına maksimum $\mathrm{BH}$ yanıtı ile boy uzaması arasındaki ilişki negatif yönde anlamlı bulundu $(p<0,05)$. Uyarı testlerine verilen maksimum yanıta göre hastalar $<3,3-5,5-7$ ve $>7 \mathrm{ng} / \mathrm{ml}$ olarak ayrıldığında, tedaviye en yüksek yanıtın hem klonidin ve hem de glukagon testlerinde $<3 \mathrm{ng} / \mathrm{ml}$ grubunda görüldüğü belirlendi. Boy uzaması ile BH dozu arasında pozitif yönde, başlangıç takvim yaşı arasında negatif yönde anlamlı bir ilişki saptandı $(p<0,05)$. Hedef boy, başlangıçtaki pubertal durum, rölatif ağırlık (RA) ve serum IGF-1 SDS'leri ile boy uzaması arasında anlamlı ilişki saptanmadı $(p>0,05)$.

Sonuç: Tedaviye erken bașlanan, uyarı testlerinde daha düşük BH yanıtı veren ve daha yüksek doz $\mathrm{BH}$ verilen hastaların tedaviden daha çok yarar gördüğü saptandı. $\mathrm{Bu}$ nedenle, BH eksikliği tanı kriterlerinin gözden geçirilmesi gerektiği, uyarı testlerinde kabul edilen $10 \mathrm{ng} / \mathrm{ml}$ sınırının aşıı tanı konmasına neden olabileceği görüldü. Daha geniş serilerde yapılacak araştırmalarda nihai boyların da değerlendirilmesi ile tanı kriterlerinin yeniden belirlenmesi gerektiği vurgulandı. (Güncel Pediatri 2012; 10: 74-9)

Anahtar kelimeler: Büyüme hormonu eksikliği, büyüme hormonu tedavisi

\section{SUMMARY}

Introduction: In this study, we aimed to investigate the factors that determine response to growth hormone $(\mathrm{GH})$ treatment in children with isolated idiopathic $\mathrm{GH}$ deficiency treated in our university hospital.

Materials and Methods: The data of 149 patients followed in our university hospital between January 1995 and December 2005 were evaluated in patient charts retrospectively.

Results: The maximum GH response to clonidine and glucagon stimulation tests was 4.58 and $6.01 \mathrm{ng} / \mathrm{ml}$ respectively. The mean GH dose was $0.215(0.18-0.25) \mathrm{mg} / \mathrm{kg} /$ week. Height SDS significantly increased after the first and second years of GH treatment $(p<0.05)$. There was a negative correlation between the maximum response to stimulation tests and the response to $\mathrm{GH}$ treatment $(\mathrm{p}<0.05)$. When the patients were grouped according to the maximum response to stimuli as $<3,3-5,5-7$, and $>7 \mathrm{ng} / \mathrm{ml}$, the best response to therapy was observed in the group with the least response $(<3 \mathrm{ng} / \mathrm{ml})$ to both clonidine and glucagon stimulation tests. A positive correlation was determined between height gain and $\mathrm{GH}$ dose, and a negative correlation between height gain and age at the beginning of therapy $(p<0.05)$. There was no correlation between target height, baseline pubertal stage, relative weight and IGF-1 SDS with the response to $\mathrm{GH}$ treatment $(p>0.05)$. 
Conclusions: Patients who were started treatment at an early age, whose response to $\mathrm{GH}$ stimulation tests were lower, and who were given higher doses benefited more from $\mathrm{GH}$ treatment. Therefore, we suggest that the diagnostic criteria for $\mathrm{GH}$ deficiency must be reevaluated and the random cut-off of $<10 \mathrm{ng} / \mathrm{ml}$ for stimulated GH level may lead to overdiagnosis. This issue must be further investigated in larger patient populations with consideration of final height as well. (Journal of Current Pediatrics 2012; 10: 74-9)

Key words: Growth hormone deficiency, growth hormone treatment

\section{Giriș}

BH eksikliğinde BH tedavisi ile büyüme hızının ve nihai boyun artırılabildiği birçok çalışma ile gösterilmiştir (1-4). $\mathrm{BH}$ tedavisine yanıtı belirleyen etkenler de birçok araştırma ile değerlendirilmiştir (5-8). Buna karşın BH eksikliğinin tanı kriterleri ve hangi çocuklara tedavi verilmesi gerektiği konusundaki tartışmalar sürmektedir.

Bu çalışmada, 10 yıllık dönem süresince $\mathrm{BH}$ eksikliği saptanan ve tedavi uygulanan hastalar incelenmiştir. $\mathrm{Bu}$ hastaların tedaviye yanitları ile bunu belirleyen etkenlerin araştırıması amaçlanmıştır.

\section{Gereç ve Yöntem}

Uludağ Üniversitesi Tıp Fakültesi Çocuk Sağlığı ve Hastalıkları Çocuk Endokrinoloji Polikliniğínde Ocak 1995Aralık 2005 tarihleri arasında izole idyopatik BH eksikliği nedeniyle takip edilen ve $\mathrm{BH}$ tedavisi kullanan hastaların verileri retrospektif olarak incelendi. Polikliniğimize başvurusundan önce başka bir merkezde tedavi başlanan ve Turner sendromu, birden fazla hormon eksikliği ya da sistemik hastalık veya santral sinir sisteminden kaynaklanan tümörü olan hastalar çalıșma dıșı bırakıldı. Hastaların dosyalarından; her kontrollerindeki puberte evreleri, fizik muayene bulguları, boy ve ağırlık ölçümleri, kullandıkları ilaç dozları değerlendirildi. Kemik yaşları için el bilek grafilerine film arşivinden ulaşılarak ve halen kontroldeki hastalardan istenerek, Greulich-Pyle (9) metoduyla değerlendirildi ve kemik yaşları ortalamaları alındı. Boy Harpenden stadyometresi, ağırlık standart elektronik tartı (SECA ®) ile ölçüldü. Boy ve ağırık değerlendirilmesinde Neyzi ve ark.'nın (10) Türk çocukları için hazırlanmış büyüme çizelgelerinden faydalanıldı. Anne-baba boyu ölçülerek hedef boy belirlendi. IGF-1 düzeylerine bakıldı.

$\mathrm{BH}$ eksikliği klonidin ve glukagon ile $\mathrm{BH}$ uyarı testleri ile araştıııldı ve her iki testte de maksimum yanıtın $10 \mathrm{ng} / \mathrm{ml}$ altında olması tanısal kabul edildi (11). Hastalar, uyarı testlerine verdikleri maksimum yanıta göre $<3,3-5,5-7$ ve $>7 \mathrm{ng} / \mathrm{ml}$ olmak üzere dört gruba ayrılarak tedaviye yanıt açısından karşılaştıııldı. Ayrıca, BH tedavisine yanııın değerlendirilmesinde hedef boy, tedavi öncesindeki rölatif ağırlık (RA), puberte durumu, kemik yaşı (KY) ve bazal IGF1 düzeyi dikkate alındı.

SPSS 16.0 istatistik programı kullanılarak değişkenler arasındaki ilişkiler incelendi. Verilerin normal dağılım gösterip göstermediği Shapiro-Wilk testi ile incelendi. Normal dağılım göstermeyen iki grup değişkenleri arasındaki fark Mann Whitney $U$ testi ile karşılaştıııldı. Normal dağılım göstermeyen değişkenler için bağımlı iki grup karşılaştırılmasında Wilcoxon Signed ranks testi kullanıldı. Ortancalar ile birlikte minimum ve maksimum değerler verildi. Anlamlıık düzeyi; $\alpha=0,05(p<0,05)$ olarak alındı.

\section{Bulgular}

Izole ve idyopatik BH eksikliği tanısı konan 149 (92 erkek, $57 \mathrm{kız}$ ) hasta çalışmaya alındı. Erkek/kız oranı 1,6 bulundu. Ortalama maksimum $\mathrm{BH}$ yanıtı klonidin stimülasyon testinde $4,58(0,05-40)$, glukagon stimülasyon testinde ise 6,01 (0,05-40) ng/ml idi.

Tedavide kullanılan BH dozları, ortalama 0,215 $(0,18$ $0,25) \mathrm{mg} / \mathrm{kg} / \mathrm{hafta}$ olarak belirlendi. Ortalama boy standart deviasyon skoru (SDS) tedavi öncesi -3'ten ikinci yılın sonunda $-2,04$ 'e yükseldi $(p<0,05)$.

İki yıllık izlem süresinde, hastaların hedef boyları ile $\mathrm{BH}$ tedavisine verdikleri yanıt arasında anlamlı bir ilişki saptanmadı $(p>0,05)$.

Hastalarımızın başlangıç RA'ları ile boy SDS'lerin değişimi arasındaki ilişkiyi değerlendirdiğimizde; birinci ve ikinci yıl sonu boy SDS'leri arasında istatistiksel olarak anlamlı bir ilişki saptanmadı ( $p=0,357)(p=0,432)$ (Tablo 1).

Tedavi öncesi prepubertal ve pubertal olan hasta gruplarının her ikisinde de tedavinin hem birinci, hem de ikinci yllı sonunda boy SDS değeri arttı $(p<0,05)$ (Tablo 2). İki grup arasında başlangıçtaki ve tedavi süresince kazanılan boy SDS değerleri arasında fark yoktu $(p>0,05)$.

Tablo 1. Başlangıç RA ile tedavinin 1. ve 2. yılı sonundaki boy SDS farkının değerlendirilmesi

\begin{tabular}{|l|c|c|}
\hline & Boy SDS Farkı 1. Yוl & Boy SDS Farkı 2. Yıl \\
\hline$r$ & 0,150 & 0,066 \\
\hline$p$ & 0,068 & 0,447 \\
\hline
\end{tabular}


Hastalarımızın tanı aşamasında bakılan klonidin uyarısına maksimum $\mathrm{BH}$ yanıtı ile boy uzaması arasındaki ilişkiyi değerlendirdiğimizde, birinci yılda ters yönde anlamlı bir ilişki saptandı $(p<0,05)$ (Şekil 1). Ancak ikinci yıl için yapılan istatistiksel analiz anlamlı bulunmadı $(p=0,052)$. Glukagon uyarı testine maksimum $\mathrm{BH}$ yanıtı ile boy uzaması arasındaki ilişkiyi değerlendirdiğimizde, hem birinci yıl sonunda, hem de ikinci yıl sonunda ters yönde anlamlı bir ilişki saptandı $(p<0,05)$ (Şekil 2).

\begin{tabular}{|c|c|c|c|}
\hline & Başvuru & 1. yll & 2. yll \\
\hline Prepubertal & $-3,00$ & $-2,32$ & $-2,1$ \\
\hline$P$ & & $p<0,05$ & $p<0,05$ \\
\hline Pubertal & $-3,00$ & $-2,42$ & $-1,91$ \\
\hline$P$ & & $p<0,05$ & $p<0,05$ \\
\hline
\end{tabular}

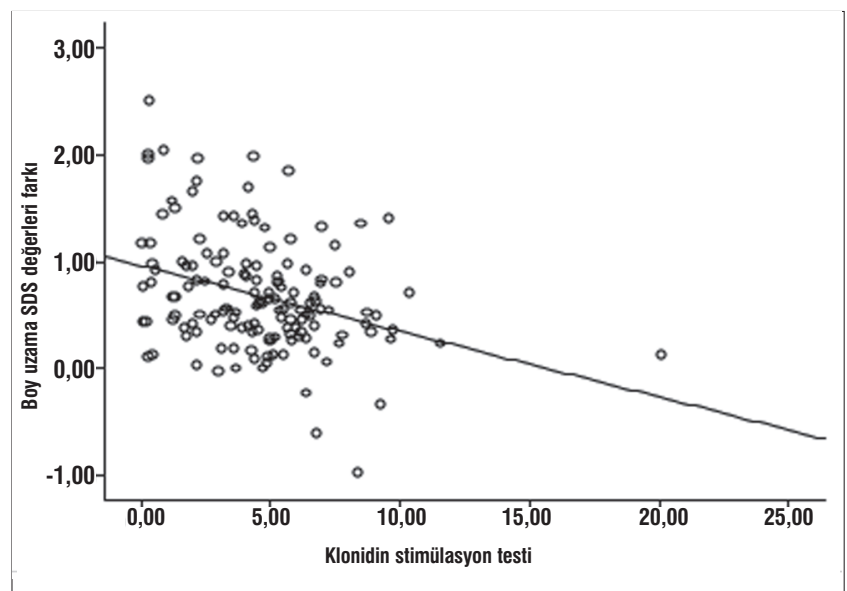

Şekil 1. Boy SDS farkı ile klonidin stimülasyon testinin ilişkisi (r:--325)



Şekil 2. Boy SDS farkı ile glukagon stimülasyon testinin ilişkisi (r:-,262)

\begin{tabular}{|c|c|c|c|}
\hline & & Boy SDS Farkı 1. yıl & Boy SDS Farkı 2. yıl \\
\hline$<3 \mathrm{ng} / \mathrm{ml}$ & $\begin{array}{l}\mathrm{n} \\
\text { Minimum } \\
\text { Maksimum } \\
\text { Ortalama } \\
\end{array}$ & $\begin{array}{c}42 \\
0,03 \\
2,49 \\
0,815\end{array}$ & $\begin{array}{c}38 \\
-0,08 \\
1,73 \\
0,355\end{array}$ \\
\hline $3-5 \mathrm{ng} / \mathrm{ml}$ & $\begin{array}{l}\mathrm{n} \\
\text { Minimum } \\
\text { Maksimum } \\
\text { Ortalama } \\
\end{array}$ & $\begin{array}{c}44 \\
-, 003 \\
1,98 \\
0,605 \\
\end{array}$ & $\begin{array}{c}42 \\
-0,72 \\
1,04 \\
0,41 \\
\end{array}$ \\
\hline $5-7 \mathrm{ng} / \mathrm{ml}$ & $\begin{array}{l}\mathrm{n} \\
\text { Minimum } \\
\text { Maksimum } \\
\text { Ortalama } \\
\end{array}$ & $\begin{array}{c}42 \\
-0,60 \\
1,84 \\
0,52 \\
\end{array}$ & $\begin{array}{c}37 \\
-0,45 \\
1,08 \\
0,23 \\
\end{array}$ \\
\hline$>7 \mathrm{ng} / \mathrm{ml}$ & $\begin{array}{l}\mathrm{n} \\
\text { Minimum } \\
\text { Maksimum } \\
\text { Ortalama }\end{array}$ & $\begin{array}{c}21 \\
-0,98 \\
1,39 \\
0,42\end{array}$ & $\begin{array}{c}17 \\
-0,10 \\
0,76 \\
0,24\end{array}$ \\
\hline Total & $\begin{array}{l}\mathrm{n} \\
\text { Minimum } \\
\text { Maksimum } \\
\text { Ortalama }\end{array}$ & $\begin{array}{c}149 \\
-0,98 \\
2,49 \\
0,580\end{array}$ & $\begin{array}{c}134 \\
-0,72 \\
1,73 \\
0,335\end{array}$ \\
\hline
\end{tabular}

Tablo 4. BH tedavisine birinci yıl yanıtının glukagon stimülasyon testi sonuçlarına göre gösterimi

\begin{tabular}{|l|l|c|c|}
\hline & & Boy SDS Fark 1. yll & Boy SDS Fark 2. yl \\
\hline$<3 \mathrm{ng} / \mathrm{ml}$ & $\mathrm{n}$ & 31 & 28 \\
& Minimum & $-0,60$ & $-0,29$ \\
& Maksimum & 2,49 & 1,21 \\
& Ortalama & 0,88 & 0,36 \\
\hline $3-5 \mathrm{ng} / \mathrm{ml}$ & $\mathrm{n}$ & 28 & 23 \\
& Minimum & $-0,98$ & $-0,23$ \\
& Maksimum & 1,65 & 1,73 \\
& Ortalama & 0,50 & 0,40 \\
\hline $5-7 \mathrm{ng} / \mathrm{ml}$ & $\mathrm{n}$ & 37 & 32 \\
& Minimum & $-0,34$ & $-0,33$ \\
& Maksimum & 1,98 & 1,08 \\
& Ortalama & 0,49 & 0,31 \\
\hline$>7 \mathrm{ng} / \mathrm{ml}$ & $\mathrm{n}$ & 53 & 51 \\
& Minimum & $-0,23$ & $-0,72$ \\
& Maksimum & 1,41 & 1,04 \\
& Ortalama & 0,55 & 0,28 \\
\hline Total & $\mathrm{n}$ & 149 & 134 \\
& Minimum & $-0,98$ & $-0,72$ \\
& Maksimum & 2,49 & 1,73 \\
& Ortalama & 0,580 & 0,335 \\
\hline
\end{tabular}


Tablo 5. BH tedavisine birinci yıl yanıtının klonidin stimülasyon testi sonuçlarına göre değerlendirilmesi

\begin{tabular}{|c|c|c|c|c|}
\hline & $<3 \mathrm{ng} / \mathrm{ml}$ & $3-5 \mathrm{ng} / \mathrm{ml}$ & $5-7 \mathrm{ng} / \mathrm{ml}$ & $>7 \mathrm{ng} / \mathrm{ml}$ \\
\hline$<3 \mathrm{ng} / \mathrm{ml}$ & & $<0,05$ & $<0,05$ & $<0,05$ \\
\hline $3-5 \mathrm{ng} / \mathrm{ml}$ & $<0,05$ & & 0,207 & 0,185 \\
\hline $5-7 \mathrm{ng} / \mathrm{ml}$ & $<0,05$ & 0,207 & & 0,56 \\
\hline$>7 \mathrm{ng} / \mathrm{ml}$ & $<0,05$ & 0,185 & 0,56 & \\
\hline
\end{tabular}

Tablo 6. BH tedavisine birinci yıl yanıtının glukagon stimülasyon testi sonuçlarına göre değerlendirilmesi

\begin{tabular}{|l|c|c|c|c|}
\hline & $<3 \mathbf{n g} / \mathrm{ml}$ & $\mathbf{3 - 5} \mathbf{~ n g} / \mathrm{ml}$ & $\mathbf{5 - 7} \mathbf{~ n g} / \mathbf{m l}$ & $>\mathbf{7 ~ n g} / \mathbf{m l}$ \\
\hline$<3 \mathrm{ng} / \mathrm{ml}$ & & $<0,05$ & $<0,05$ & $<0,05$ \\
\hline $3-5 \mathrm{ng} / \mathrm{ml}$ & $<0,05$ & & 0,207 & 0,185 \\
\hline $5-7 \mathrm{ng} / \mathrm{ml}$ & $<0,05$ & 0,207 & & 0,56 \\
\hline$>7 \mathrm{ng} / \mathrm{ml}$ & $<0,05$ & 0,185 & 0,56 & \\
\hline
\end{tabular}

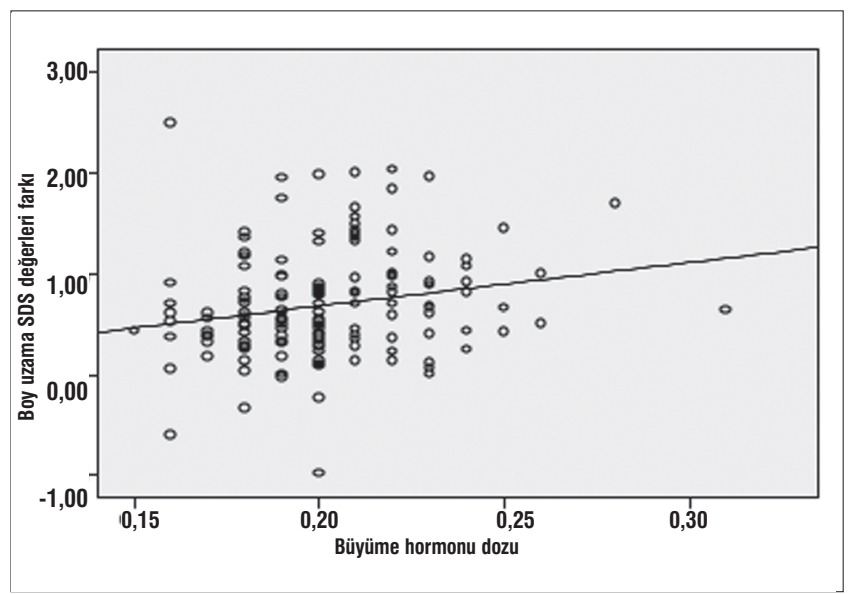

Şekil 3. Boy SDS farkı ile BH dozu arasındaki ilişki (r: 0,204)

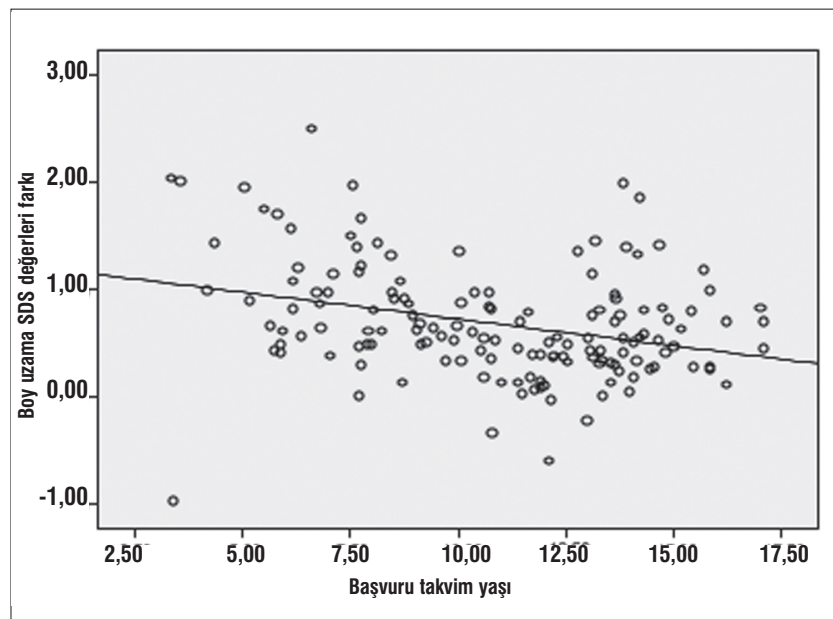

Şekil 4. Boy SDS farkı ile başvuru takvim yaşı arasındaki ilişki (r:- 0,311)
Klonidin ve glukagon uyarı testi sonuçlarını $<3 \mathrm{ng} / \mathrm{ml}, 3-$ $5 \mathrm{ng} / \mathrm{ml}, 5-7 \mathrm{ng} / \mathrm{ml}$ ve $>7 \mathrm{ng} / \mathrm{ml}$ olarak dört gruba ayırdık. Bu gruplar BH tedavisine yanıtı açısından karşılaştıııldığında; birinci yıl için gruplar arasında istatistiksel olarak anlamlı bir ilişki saptandı $(p<0,05)$. Ancak ikinci yıl için anlamlı ilişki bulunmadı ( $p=0,157$ ) (Tablo 3,4,5,6).

Tedavide kullanılan BH dozuyla tedaviye yanıt arasındaki ilişki için yaptığımız değerlendirmede, birinci yıl sonunda aynı yönde istatistiksel olarak anlamlı bir ilişki bulundu $(p<0,05)$, fakat ikinci yıl için anlamlı bir ilişki bulunmadı $(\mathrm{p}=0,26)$ (Şekil 3). Hastalarımızın başvuru takvim yaşı (TY) ile boy uzaması arasındaki ilişkiyi incelediğimizde; birinci yılda ters yönde anlamlı bir ilişki saptandı $(p<0,05)$. Íkinci yıl için yapılan değerlendirmede anlamlı bir ilişki saptanmadı $(p=0,99)$ (Şekil 4). Tanı sırasında baktığımız serum IGF-1 düzeyi SDS'leri ile boy uzaması arasında istatistiksel olarak anlamlı bir ilişki saptanmadı $(\mathrm{p}=0,120)$ (Tablo 7).

Toplam 32 hastamız nihai boya ulaştı. Bunlardan 10 hasta epifizler kapandığı için hedef boya ulaşamadı. Geri kalan 22 hasta hedef boya ulaştı.

\section{Tartışma}

$\mathrm{BH}$ tedavisi kullanan hastalarımızda erkek/kız oranını 1,6 olarak saptadık. KIGS verilerine göre de dünyada bu oran 2,2 olarak rapor edilmiştir (12). Bu durum erkek hastaların sosyal nedenlerle endokrin kliniklerine daha sık başvurmaları veya erkek hastalarda BH eksikliğine genetik yatkınlığın daha fazla olması ile açıklanabilir.

Tedaviye verilen cevap değerlendirildiğinde; tüm olguların özellikle tedavinin ilk yllında BH'na verdiği cevap olumluydu. Hastaların bir yıllık boy SDS'leri -3'ten birinci yıl sonunda $-2,35$ 'e yükseldi. $(p<0,05)$. Büyüme hızı ilk yılda ortalama $10,8 \mathrm{~cm}$ bulunurken daha sonra kademeli olarak 2. yılda azaldığı görüldü. Yapılan diğer çalışmalarda da BH tedavisi ile ilk yıldaki büyüme hızları 7,5 cm ile $12 \mathrm{~cm}$ arasındayken daha sonraki yıllarda tedaviye rağmen uzama hızlarının hastalarımıza benzer şekilde kademeli olarak azaldığı bildirilmiştir $(3,13)$. BH tedavisine ilk yıldan

Tablo 7. BH dozu, başvuru TY ve IGF-1 SDS ile boy uzaması arasındaki ilişki

\begin{tabular}{|l|c|c|c|}
\hline \multirow{2}{*}{ BH Dozu } & & Boy Uzaması 1. Yıl & Boy Uzaması 2. Yıl \\
\cline { 2 - 4 } & $\mathrm{r}$ & 0,204 & $-0,097$ \\
\hline \multirow{2}{*}{ Başvuru TY } & $\mathrm{r}$ & $<, 05$ & 0,267 \\
\cline { 2 - 4 } & $\mathrm{p}$ & $-0,311$ & $-0,006$ \\
\hline \multirow{2}{*}{ IGF-1 SDS } & $\mathrm{r}$ & $<, 05$ & 0,94 \\
\cline { 2 - 4 } & $\mathrm{p}$ & 0,160 & $-0,016$ \\
& & 0,120 & 0,883 \\
\hline
\end{tabular}


sonra verilen cevabın neden azaldığı henüz net anlaşılamamıştır (13).

Prepubertal ve pubertal grubun tedavi öncesi ve sonrası boy SDS ve kazanılmış boy SDS'leri arasında fark olmadığı saptandı. Literatürde BH tedavisi sonuçlarını, tedavinin puberte öncesi ve sonrasında başlanmasına göre değerlendiren pek çok çalışma vardır. Ranke ve ark. (5) 51 prepubertal ve 66 pubertal çocuğun $\mathrm{BH}$ tedavi sonuçlarını değerlendirmiş, prepubertal grupta ortalama nihai boy SDS değerini $-0,5$ ve kazanılan boy SDS değerini 2,3 olarak bildirmiştir. Puberteden sonra BH tedavisi alan hastalarda bu değerler sırasıyla $-1,3$ ve 1,4'tür. Coste ve ark.'nın (4) yaptığı çalışmada aradaki farkı daha küçük bulsalar da, prepubertal BH tedavisi başlanan çocukların nihai boy SDS ve kazanılan boy SDS değerini daha yüksek olarak rapor etmişlerdir. Dündar ve ark. (14) ise boy SDS ve kazanılmış boy SDS oranları arasında fark olmasa da, tedavi sonrası öngörülen erişkin boy SDS değerini prepubertal grupta $-0,96 \pm 0,98$, pubertal grupta ise $-1,49 \pm 0,8$ olarak saptamışlardır. Bilindiği üzere pubertal büyüme hamlesi erişkin boyun belirlenmesinde önemlidir. Pubertal dönemde ortalama erkeklerde $28 \mathrm{~cm}$, kılarda $25 \mathrm{~cm}$ boy uzaması olmaktadır (15). Puberteye kadar olan büyüme ile erişkin boyunun \%85-90'ı sağlanmaktadır. Hastalar puberteye ne kadar yüksek boyla girerlerse boyları da 0 kadar iyi olmaktadır. Bu durum BH tedavisinin prepubertal başlanmasının önemini ortaya koymaktadır.

Tedaviye yanıtı belirleyen etkenler arasında, başlangıçtaki RA değerinin yüksek olmasının yanıtı olumlu etkileyeceğini öngörmüştük. Cole ve ark. (6) tedavi başlangıcında kısa ve şişman çocukların BH tedavisine daha iyi yanıt verdiklerini bildirmiş̧ir. Çalışmamızda ise hem birinci, hem de ikinci yıl için istatistiksel olarak anlamlı bir ilişki saptanmamışıır. Hastaların hedef boyları ile iki yıllık $\mathrm{BH}$ tedavisine yanıtları arasında da korelasyon saptanmamıştır. Ancak bu ilişki hastaların nihai boylarına ulaşmasından sonra tekrar değerlendirilmelidir.

Çalışmamızda, hastalarımızın tanı aşamasında bakılan klonidin ve glukagon uyarı testine maksimum $\mathrm{BH}$ yanıtı ile boy uzaması arasındaki ilişki değerlendirildi. Klonidin ve glukagon uyarı test sonuçları düşük çıkanlarda $\mathrm{BH}$ tedavisine verilen cevabın daha olumlu olacağını öngördük. Cole ve ark.'nın (6) yaptığı iki yıllık bir çalışmada da provokasyon test sonuçları ile tedavi sonrası boy uzaması arasında anlamlı ve negatif bir ilişki bulunmuştur. Ranke ve ark. (7), provokasyon test sonuçlarının tedavi sonrası boy uzaması için önemli bir belirteç olduğunu saptamışlardır. Bizim çalışmamızda; klonidin uyarı testi için, birinci yılda ters yönde anlamlı bir ilişki saptandı $(p<0,05)$. Ancak ikinci yıl için yapılan istatistiksel analiz sınırda anlamsız bulundu ( $p=0,052)$. Glukagon uyarı testi için hem birinci yıl sonunda, hem de ikinci yıl sonunda ters yönde anlamlı bir ilişki saptandı $(p<0,05)$. Bu durumu daha detaylandırmak için klonidin ve glukagon uyarı testi sonuçlarını dört gruba ayırdık (<3ng/ml, 3-5ng/ml, $5-7$ ng/ml ve $>7 \mathrm{ng} / \mathrm{ml}$ ) ve grupların kendi aralarında boy uzamasına etkilerini inceledik. Hastalarımızın hem klonidin, hem de glukagon uyarı testlerinde $<3 \mathrm{ng} / \mathrm{ml}$ ile diğer 3 grup arasında boy uzaması yönünden istatistiksel olarak anlamlı bir ilişki saptandı $(p<0,05)$. Bu durum hastanın tanı aşamasında bakılan klonidin/glukagon uyarı testlerinin ne kadar düşük olursa tedaviye verecekleri cevabın o kadar olumlu olacağını göstermektedir $(6,7)$.

Çalışmamızda; tedavide kullanılan BH dozuyla tedaviye verilen yanıt arasındaki ilişkiyi değerlendirdiğimizde; öngörümüz, BH tedavisinin yüksek dozlarda kullanılmasıyla beraber boy uzamasının daha olumlu olacağı yönündeydi. Çalışmamızda, birinci yıl sonunda hipotezimize uygun olarak aynı yönde istatistiksel olarak anlamlı bir ilişki bulundu; fakat ikinci yı için anlamlı bir ilişki saptanmadı. Cole ve ark.'nın (6) yaptığı çalışmada, total BH tedavi dozu ile boy uzaması arasında anlamlı bir ilişki bulunmamış, fakat enjeksiyon sıklığının önemli olduğu saptanmıştır. Haftada 6-7 doz enjeksiyon uygulananların boy uzamasının daha fazla olduğu görülmüştür. Bizim çalışmamızda da tüm hastalarımıza 6-7/hafta şeklinde enjeksiyon sıklığı uygulanmıştır.

Literatürde BH tedavisine ne kadar erken başlanırsa, tedaviye verilen cevabın o kadar iyi olacağı bildirilmektedir. Bu bilgiyle uyumlu olarak birinci yılda negatif yönde anlamlı bir ilişki saptandı; fakat ikinci yıl için yapılan değerlendirmede anlamlı bir ilişki bulunmadı. Cole ve ark. (6) tedaviye küçük yaşta başlayan çocukların boy SDS değişiminin daha anlamlı arttığını göstermişlerdir.

Çalışmamızda, serum IGF-1 SDS'leri ile boy uzaması arasında istatistiksel olarak anlamlı bir ilişki saptanmadı. Serum IGF-1 düzeyi BH eksikliği tanısı için bir tarama testi olarak kullanılmakla birlikte eksikliğin derecesi ile ilişkili bulunmamıştır (8). Bu nedenle tedaviye yanıtın öngörülmesi konusunda da değerli bir parametre değildir. Bizim bulgularımız da bu görüşü desteklemektedir.

Sonuç olarak, tedaviye erken başlanan, uyarı testlerinde daha düşük $\mathrm{BH}$ yanıtı veren ve daha yüksek doz $\mathrm{BH}$ verilen hastalar tedaviden daha çok yarar görmüştür. $\mathrm{Bu}$ nedenle, BH eksikliği tanı kriterlerinin gözden geçirilmesi gerektiği, uyarı testlerinde kabul edilen $10 \mathrm{ng} / \mathrm{ml}$ sınııının aşırı tanı konmasına neden olabileceği düşünülmelidir. Daha geniş serilerde yapılacak araştırmalarda nihai boyların da değerlendirilmesi ile tanı kriterlerinin yeniden belirlenmesi gerekebilir. 


\section{Kaynaklar}

1. Allen DB, Johanson AJ, Blizzard RM: Growth hormone treatment; In Lifshitz $\mathrm{F}$ (ed): Pediatric Endocrinology. 3rd edition. New York: Marcel Dekker; 1996. 61-81.

2. Guyda HJ. Four decades of growth hormone therapy for short children: what have we achieved? J Clin Endocrinol Metab 1999;84:4307-16.

3. Bundak R, Hindmarsh PC, Brook CG. Long-term auxologic effects of human growth hormone. J Pediatr 1988;112:875-9.

4. Coste J, Letrait M, Carel JC, Tresca JP, Chatelain P, Rochiccioli P, et al. Long term results of growth hormone treatment in France in children of short stature: population, register based study. BMJ 1997;315:708-13.

5. Ranke MB, Price DA, Albertsson-Wikland K, Maes M, Lindberg A. Factors determining pubertal growth and final height in growth hormone treatment of idiopathic growth hormone deficiency. Analysis of 195 Patients of the Kabi Pharmacia International Growth Study. Horm Res 1997:48:62-71.

6. Cole TJ, Hindmarsh PC, Dunger DB. Growth hormone (GH) provocation tests and the response to $\mathrm{GH}$ treatment in $\mathrm{GH}$ deficiency. Arch Dis Child 2004;89:1024-7.

7. Ranke MB, Lindberg A, Chatelain P, Wilton P, Cutfield W, Albertsson-Wikland $K$, et al. Derivation and validation of a mathematical model for predicting the response to exogenous recombinant human growth hormone $(\mathrm{GH})$ in prepubertal children with idiopathic GH deficiency. KIGS International Board. Kabi Pharmacia International Growth Study. J Clin Endocrinol Metab 1999:84:1174-83.
8. Nathan BM, Allen DB. Growth Hormone Treatment. In: Lifshitz F (eds). Pediatric Endocrinology. 5rd edition. New York: Informa; 2007:113-43

9. Greulich WW, Pyle SI, (eds) Radiographic atlas of skeletal development of the hand and wrist. Second edition, Stanford University Press; 1959.

10. Neyzi 0, Günöz H, Furman A, Bundak R, Gökçay G, Darendeliler $F_{\text {, }}$ et al. Türk çocuklarında vücut ağırlı̆ı̆, boy uzunluğu, baş çevresi ve vücut kitle indeksi referans değerleri. Çocuk Sağlığı ve Hastalıkları Dergisi 2008;51:1-14.

11. Lifshitz F, Botero D. Growth and growth disorders In: Lifshitz F. (eds). Pediatric Endocrinology. 4rd edition. Newyork: MarcelDekker; 2004:1-18.

12. Chatelain P. Trends in the diagnosis and treatment of short stature as revealed by KIGS In: Ranke MB and Wilton P (eds): Growth Hormone Therapy in KIGS 10 Years Experience. Heidelberg: Leipzig: Barth J\&J;1999. 11-20.

13. Reiter EO, Rosenfeld RG. Normal and aberrant growth In: Wilson ID, Foster DW, Kronenberg HM, Larsen PR (eds): Williams Text Book of Endocrinology. 9th edition. Philadelphia: WB Saninders Company; 1998. 1427-507.

14. Dündar B, Böber $E$, Büyükgebiz $A$. Results of growth hormone treatment applied during twelve years period in Dokuz Eylül University, school of medicine, Department of Pediatric Endocrinology. Dokuz Eylül Üniversitesi Tıp Fakültesi Dergisi 2004;18: 55-65.

15. Tanner JM, Whitehouse RH, Marubini E, Resele LF. The adolescent growth spurt of boys and girls of the Harpenden growth study. Ann Hum Biol 1976;3:109-26. 